\title{
HUBUNGAN ANTARA KOMPETENSI SOSIAL DAN KEPERCAYAAN DIRI PADA SISWA
}

\author{
Dina Hazadiyah, N .Kardinah, dan Imam Sunardi \\ Fakultas Psikologi UIN Sunan Gunung Djati Bandung, Jl. A.H Nasution No. 105 Bandung \\ email: n.kardinah@gmail.com
}

\begin{abstract}
Abstrak
Penelitian ini menggunakan pendekatan non-eksperimental dengan teknik korelasional untuk mengetahui apakah ada hubungan antara kompetensi sosial dengan kepercayaan diri. Purposive sampling diambil dari populasi siswa Kelas X Madrasah Aliyah Negeri 2 Kota Bandung yang berjumlah 343 orang. Pengumpulan data dilakukan dengan menggunakan skala kompetensi sosial dan kepercayaan diri. Hasil menunjukkan terdapat hubungan yang signifikan antara kompetensi sosial dengan kepercayaan diri pada siswa dengan koefisien korelasi sebesar 0,565 dan sigificancy level $(0,000)$. Kompetensi sosial yang tinggi membuat tingkat kepercayaan diri tinggi tetapi jika kompetensi sosial rendah maka tingkat kepercayaan diri juga menjadi rendah.
\end{abstract}

Kata kunci : Kompetensi sosial, Kepercayaan Diri

This research used non-experimental approach with correlational technique studying whether social competency correlated with self-esteem. Purposive sampling were taken from 343 students of grade X Madrasah Aliyah Negeri 2 Kota Bandung. Data were collected using social competency scale and self-esteem scale. Result shows that there is significant correlation between social competency and self-esteem with cooficient correlation 0,565 at significancy level (0,000). High social competency produce highself-esteem whereas low social competency result low self-esteem.

Keywords : social competency, self-esteem

\section{PENDAHULUAN}

Masa remaja merupakan masa transisi. Terjadi pada usia kurang lebih lima belas tahun sampai dengan dua puluh dua tahun. Pada masa tersebut, remaja akan mengalami beberapa kejadian seperti pencarian jati diri, senang bereksplorasi, mengalami tekanan sosial, maupun adanya perubahan-perubahan yang lainnya dalam bentuk fisik maupun psikis. Perubahan yang terjadi pada remaja tidak terlepas dari berbagai macam pengaruh, seperti dari lingkungan sekitar rumah, keluarga, sekolah, dan teman-teman sebaya, serta aktivitas-aktivitas yang dilakukannya dalam kehidupan sehari-hari. Masa remaja yang identik dengan lingkungan sosial tempat beraktivitas, membuat mereka dituntut untuk dapat menyesuaikan diri secara efektif.

Di lingkungan masyarakat maupun sekolah, remaja memiliki beberapa masalah yang harus dihadapinya. Masalah yang dihadapi salah satunya adalah kurangnya rasa percaya diri pada siswa 
dikarenakan masih adanya rasa malu maupun rasa takut untuk berhubungan sosial dengan teman lainnya. Remaja dalam berhubungan sosial dengan orang lain memerlukan rasa percaya diri.

Proses berlangsungnya percaya diri terjadi sejak usia dini, dalam kehidupan bersama orang tua. Faktor yang amat berpengaruh ialah interaksi di usia dini. Dalam menumbuhkan dan memupuk rasa percaya diri diperlukan untuk memulainya dari dalam diri individu itu sendiri. Contohnya bisa melakukan sesuatu yang diiinginkan dengan berani yaitu berani mengambil resiko, berpikir positif, dan mensukuri serta menikmati rahmat Tuhan.

Setiap siswa memiliki lingkungan dan latar belakang yang berbeda-beda, sehingga hal itu bisa memengaruhi kepribadian dan juga pembentukan rasa percaya diri dan cara interaksi sosial dengan lingkungan sekitarnya. Dengan rasa percaya diri yang dimilikinya, siswa akan mudah berinteraksi di dalam lingkungan belajarnya. Kelemahan pada generasi muda atau remaja adalah kurangnya rasa percaya diri. Rasa kurang percaya diri akan menimbulkan rasa takut yang berarti kurangnya pengetahuan dan pengertian pada anak. Dalam kehidupan remaja, remaja menemukan banyak kegagalan dan perlu menyiapkan diri untuk memasuki tahapan kehidupan dengan penuh kesuksesan. Rasa percaya diri seharusnya ada pada setiap orang untuk modal menuju kesuksesan. Sementara tidak percaya diri itu racun dari kesuksesan dan keberhasilan.

Dalam melakukan suatu kegiatan maupun pekerjaan, semua orang memiliki kemampuan dan keinginan yang berbedabeda. Salah satu faktor yang membuat individu dapat melakukan apa yang dia ingin lakukan adalah ketika dia memiliki rasa percaya diri yang cukup untuk melakukannya. Ketika seseorang kurang memiliki rasa percaya diri maka kemungkinan orang tersebut tidak akan dapat bergaul dengan sesama temannya dan melakukan sesuai dengan apa yang diinginkannya. Kemudian dengan sikap percaya diri bisa mengembangkan dan memperbaiki diri serta melakukan motivasi. Berdasarkan uraian tersebut bahwa kepercayaan diri sangat penting dalam kehidupan seseorang.

Dari hasil observasi beberapa siswa, madrasah yang diteliti disini memiliki kedisiplinan yang tinggi. Adapun untuk masalah kepercayaan diri pada siswa bahwa beberapa alasan dari mereka menyebutkan bahwa timbulnya rasa percaya diri dikarenakan adanya alasan yaitu dengan memiliki banyak teman jadi tidak minder dan tidak merasa terpojokan, adanya motivasi dari dalam dirinya, adanya kebersamaan dengan teman lainnya, ada teman yang bisa diajak untuk mengobrol, dan lain sebagainya.

Adapun dari teori menurut Waters \& Sroufe (1983), dijelaskan bahwa kemampuan kompetensi sosial jika digunakan di lingkungan oleh individu merupakan sumber untuk mencapai keberhasilan yang baik karena akibat dari hasil perkembangan. Perkembangan kompetensi sosial memberikan hal yang sangat baik ketika dijaga dalam satu ketentuan integrasi. Perkembangan yang terjadi di usia remaja terdapat beberapa isu. Bahwa setiap tingkah laku itu membutuhkan fokus yang berbeda-beda pada setiap masanya dalam kompetensi sosial. Pada masa remaja terjadi beberapa isu. Beberapa isu yang muncul pada masa remaja dalam hal kompetensi sosialnya adalah yaitu munculnya kepercayaan diri yang sering kita sebut dengan self confidence, adanya rasa keakraban dengan teman sebaya, konformitas, orientasi sosial yang positif, rasa humor, suka sama suka dan lain sebagainya.

Dari keterangan isu tersebut untuk menumbuhkan rasa percaya diri tersebut banyak hal yang perlu dilakukan. Dalam kompetensi sosial ini misalnya, berpengaruh terhadap rasa kepercayaan diri . Kompetensi sosial yang terjadi akan 
muncul, jika dalam dirinya juga terdapat rasa kepercayaan diri. Rasa kepercayaan diri seorang akan muncul jika mereka yakin dan mampu dengan apa yang mereka pahami maupun menerima segala kekurangan dan kelebihan terhadap diri sendiri. Maka percaya diri itu akan muncul salah satunya karena adanya kompetensi sosial.

Kemampuan untuk mengatasi situasi sosial dan kemungkinan tentang apa yang diinginkan maupun apa yang dibutuhkan oleh remaja disebut juga kompetensi sosial. Dengan demikian remaja membutuhkan interaksi sosial dalam menyesuaikan diri di lingkungan sekitarnya. Adanya kebutuhan untuk berinteraksi dan membutuhkan orang lain dalam hidupnya merupakan sistem hidup ataupun pola hidup yang alamiah. Hal ini disebabkan adanya kompetensi sosial yang dimiliki individu. Melalui kompetensi sosial yang berulang pada setiap waktunya akan memicu perubahan yang ada pada dalam dirinya.

Remaja yang kompeten dalam hal sosialnya mampu menggunakan keterampilan dan pengetahuannya untuk melakukan hubungan yang positif dengan orang lain. Orang yang memiliki kompetensi sosial yang tinggi akan mampu mengekspresikan perhatian sosial lebih banyak, suka menolong dan suka empatik. Adapun pandangan masyarakat terhadap anak yang berkompeten secara sosial jika perilaku mereka lebih bertanggung jawab, mandiri, tidak bergantung, dan mampu bekerjasama.

Kompetensi sosial merupakan suatu sarana untuk dapat diterima dalam lingkungan masyarakat. Dengan memiliki kompetensi sosial seseorang menjadi peka terhadap berbagai situasi sosial yang dihadapi. Remaja yang berhasil menghadapi setiap permasalahan sehubungan dengan tugas-tugas perkembangan, tuntutan masyarakat dan kejadian-kejadian hidup yang dialaminya, dengan cara-cara yang kompeten akan menghasilkan bentuk penyelesaian masalah yang akan memberikan solusi.

Hal ini sangat penting dan menentukan sekali bagi tercapainya kepuasan dan kebahagiaan hidup seseorang dan orang-orang disekitarnya. Dalam kehidupan sehari-hari sering dijumpai bahwa orang-orang yang mempunyai kompetensi sosial yang baik akan cenderung mempunyai penyesuaian diri yang baik pula.

Sehubungan dengan kompetensi sosial akan terjadi juga hubungan sosial yang merupakan hal penting pada saat di sekolah seperti halnya membangun komunikasi yang baik dengan teman, belajar bersama, dan mempunyai rasa empati dan simpati terhadap orang lain. Kondisi sosial yang baik akan membangun rasa kerjasama, rasa pengendalian, timbul semangat dan rasa percaya diri.

$\begin{array}{ccc}\text { Dalam } & \text { suatu hasil penelitian } \\ \text { terdahulu, } & \text { Tentrawanti } & \text { (1989), }\end{array}$
mengemukakan bahwa seseorang yang mempunyai kompetensi sosial adalah orang-orang yang mampu melakukan dua hal, yaitu:

1. Mampu menghadapi kondisi-kondisi yang penuh dengan ketegangan, dan

2. Mampu menarik dan mempertahankan dukungan sosial. Selanjutnya dalam suatu penelitiannya, Tentrawati (1989), juga mengemukakan bahwa seseorang yang berkompetisi sosial, memiliki ciriciri sebagai berikut:

a. Pengetahuan sosial, yaitu pengetahuan mengenai keadaan emosi yang memadai dengan konteks sosial tertentu.

b. Kepercayaan diri untuk memulai suatu tindakan dan adanya usaha untuk memecahkan masalah sendiri.

c. Empati, yaitu kemampuan menghargai perasaan orang lain sekalipun orang tersebut tidak dikenalnya atau tidak ada hubungan dengannya, juga mampu memberikan respon-respon emosional, mampu mengendalikan 
emosi dan tulus dalam menjalin hubungan dengan orang-orang yang bermasalah.

d. Sensitivitas sosial, yaitu kemampuan emosional untuk menangkap kebutuhan-kebutuhan lingkungannya. Di usia remaja, banyak terjadi interaksi sosial baik itu secara tidak langsung maupun secara langsung dengan orang lain. Hubungan dengan orang lain tersebut akan berkembang secara matang sesuai dengan usaha mereka dalam mengerti dan menilai secara obyektif orang lain. Kondisi ini menunjukkan kompetensi sosial.

Salah satu faktor yang berhubungan dengan kompetensi sosial adalah kepercayaan diri. Apakah orang yang memiliki kompetensi sosial yang baik akan menimbulkan rasa kepercayaan dirinya atau malah sebaliknya.

Berdasarkan latar belakang tersebut, maka peneliti ingin meneliti lebih jauh "Hubungan Kompetensi Sosial dan Kepercayaan Diri pada Siswa". Sebagai judul penelitiannya.

Berdasarkan uraian latar belakang di atas, peneliti ingin mengetahui yaitu "Apakah terdapat hubungan antara kompetensi sosial dan kepercayaan diri pada siswa kelas $\mathrm{X}$ Madrasah Aliyah Negeri 2 Kota Bandung?".

Maksud dari penelitian ini dilakukan untuk mengetahui bagaimanakah kompetensi sosial dan kepercayaan diri pada siswa kelas X Madrasah Aliyah Negeri 2 Kota Bandung. Untuk mengetahui masalah tersebut maka peneliti ditujukkan untuk:

1. Mengetahui gambaran kompetensi sosial pada siswa kelas X Madrasah Aliyah Negeri 2 Kota Bandung.

2. Mengetahui gambaran kepercayaan diri pada siswa kelas X Madrasah Aliyah Negeri 2 Kota Bandung.

Tujuan penelitian ini dilakukan untuk mengetahui adanya hubungan antara tingkat kompetensi sosial dan kepercayaan diri. Dengan demikian dapat ditarik kesimpulan ada atau tidaknya hubungan antara kompetensi sosial dan kepercayaan diri.

Kegunaan penelitian ini diharapkan sebagai bentuk perkembangan ilmu penelitian dan hasil dari penelitian ini dapat berguna khususnya di dunia psikologi dan disiplin ilmu lain pada umumnya.

Kegunaan penelitian ini akan berguna bagi guru, khususnya guru BK (Bimbingan Konseling) di Madrasah Aliyah Negeri 2 Kota Bandung sebagai bahan masukan informasi mengenai hubungan kompetensi sosial dan kepercayaan diri pada siswa. Sedangkan untuk peneliti sendiri diharapkan dapat memberikan tambahan ilmu pengetahuan mengenai hubungan kompetensi sosial dan kepercayaan diri pada siswa.

Sesuai dengan tujuan penelitian ini yaitu ingin mengetahui hubungan antara kompetensi sosial dengan kepercayaan diri siswa kelas X Madrasah Aliyah Negeri 2 Kota Bandung, maka dalam metode penelitian ini peneliti akan menggunakan penelitian kuantitatif korelasional. Penelitian ini bertujuan untuk menemukan ada tidaknya hubungan dan apabila ada, berapa eratnya hubungan serta berarti atau tidak hubungan itu (Arikunto,2010). Penelitian korelasional tujuannya untuk menentukan ada tidaknya hubungan dua variabel tersebut yang dapat diukur.

\section{VARIABEL PENELITIAN}

Variabel merujuk pada karakteristik atau atribut seorang individu atau suatu organisasi yang dapat diukur atau diobservasi (Creswell, 2007a). Penelitian ini ingin mengetahui hubungan dua variabel. Variabel pertama adalah kompetensi sosial dan variabel kedua adalah kepercayaan diri. Berikut variabel yang akan diteliti dalam penelitian ini:

1. Variabel pertama (X) : Kompetensi Sosial

2. Variabel kedua (Y)

Kepercayaan Diri 
Definisi konseptual, Kompetensi sosial adalah kemampuan individu untuk mencapai tujuan personal dalam interaksi sosial dengan tetap memelihara hubungan yang positif dengan orang lain setiap waktu dalam berbagai situasi (Rubin \& Krasnor, dalam Agustina tahun 2011 ).

Kepercayaan diri adalah orang yang merasa puas dengan dirinya. Orang yang percaya diri mempunyai kemampuan dan keberanian untuk meningkatkan prestasinya sendiri (Lindenfield, 1994).

Secara definisi operasional, Kompetensi Sosial adalah suatu kemampuan individu dalam berinteraksi secara efektif serta terlibat dalam situasi sosial di lingkungan. Kompetensi sosial diukur berdasarkan aspek-aspek yang dijelaskan oleh Rubin dan Krasnor (1992) yaitu sebagai berikut:

1) Kemampuan individu untuk dapat menyelesaikan masalah-masalah interpersonal yang dihadapinya secara adaptif.

2) Kemampuan individu untuk dapat terlibat secara aktif dan positif dalam interaksinya dengan teman sebaya.

Semakin tinggi skor yang dimiliki subjek maka semakin tinggi pula kompetensi sosial yang dimiliki.

Kepercayaan diri adalah individu yang memiliki sikap yang memampukan dirinya baik itu untuk penilaian positif terhadap dirinya maupun lingkungan yang dihadapinya. Kepercayaan diri diukur berdasarkan aspek-aspek yang dijelaskan oleh Lindenfield (1997) yaitu sebagai berikut:

1) Percaya diri batin adalah percaya diri yang memberi kepada kita perasaan dan anggapan bahwa kita dalam keadaan baik. Percaya diri batin memiliki empat ciri utama seseorang yaitu cinta diri, pemahaman diri, tujuan yang positif, dan pemikiran yang positif.

2) Percaya diri lahir adalah akan membuat individu memberikan kesan pada dunia luar bahwa yakin pada dirinya sendiri (percaya diri lahir). Percaya diri lahir memiliki empat ciri utama seseorang yaitu komunikasi, ketegasan, penampilan diri, dan pengendalian perasaan.

Semakin tinggi skor yang dimiliki subjek maka semakin tinggi pula kepercayaan diri yang dimiliki.

Subjek yang digunakan dalam penelitian ini memiliki karakteristik sebagai berikut:

a. Terdaftar sebagai siswa kelas $\mathrm{X}$ Madrasah Aliyah Negeri 2 Kota Bandung.

b. Usia 15-18 tahun.

c. Jenis kelamin : Laki-laki dan perempuan.

Penelitian ini dilakukan dengan menggunakan teknik pengambilan sampel yaitu Purposive Sample atau sampel bertujuan dilakukan dengan cara mengambil subjek bukan didasarkan strata, random, atau daerah tetapi didasarkan atas adanya tujuan tertentu (Arikunto, 2010).

\section{HASIL PENELITIAN}

\section{Kategori Kompetensi Sosial}

Berdasarkan hasil perhitungan menggunakan program SPSS versi 17.0 maka diperolehn bahwa jumlah responden yang terkumpul sebanyak 103 orang dan tidak ada data yang terbuang. Rata-rata skor (mean) tiap orang sebesar 74, 17. Nilai tengah (median) dari skor kompetensi sosial sebesar 75. Jadi subjek yang jumlah skornya berada di atas 75 memiliki kompetensi sosial yang tinggi sedangkan subjek yang jumlah skornya berada di bawah 75 memiliki kompetensi sosial yang rendah. Skor minimum dari skala kompetensi sosial yaitu 55 dan skor maksimumnya 91 dengan rentang antar skornya (range) adalah sebesar 36.

Kompetensi sosial dikategorikan menjadi 2 kategori yaitu kompetensi sosial tinggi dan kompetensi sosial rendah. Subjek dikategorikan memiliki frekuensi kompetensi sosial yang tinggi apabila 
skornya berada di atas atau sama dengan median. Sedangkan subjek dikategorikan memiliki frekuensi kompetensi sosial yang rendah apabila skornya berada di bawah median.Jmlah siswa yang frekuensi kompetensi sosialnya tinggi sebanyak 56 orang atau setara dengan 54,37 persen, sedangkan siswa yang kompetensi sosialnya yang rendah sebanyak 47 orang atau setara dengan 45,63 persen dari keseluruhan siswa.

\section{Kategori Kepercayaan Diri}

Berdasarkan hasil perhitungan menggunakan program SPSS versi 17.0 maka diperoleh hasil menunjukkan bahwa jumlah responden yang terkumnpul sebanyak 103 siswa dan tidak ada data yang terbuang. Rata-rata skor (mean) tiap orang sebesar 83, 54. Nilai tengah (median) dari skor kompetensi sosial sebesar 84 . Jadi subjek yang jumlah skornya berada di atas 84 memiliki kompetensi sosial yang tinggi sedangkan subjek yang jumlah skornya berada di bawah 84 memiliki kompetensi sosial yang rendah. Skor minimum dari skala kompetensi sosial yaitu 64 dan skor maksimumnya 100 dengan rentang antar skornya (range) adalah sebesar 36 .

Kepercayaan diri dikategorikan menjadi 2 kategori yaitu Kepercayaan diri tinggi dan kepercayaan diri rendah. Subjek dikategorikan memiliki frekuensi kepercayaan diri yang tinggi apabila skornya berada di atas atau sama dengan median. Sedangkan subjek dikategorikan memiliki frekuensi kepercayaan diri yang rendah apabila skornya berada di bawah median. Jumlah siswa yang frekuensi kepercayaan dirinya tinggi sebanyak 56 orang atau setara dengan 54,37 persen, sedangkan siswa yang kepercayaan dirinya yang rendah sebanyak 47 orang atau setara dengan 45,63 persen dari keseluruhan siswa.

Data yang diperoleh dari hasil tabulasi silang antara kompetensi sosial dengan kepercayaan diri, dari 103 siswa terdapat 56 siswa yang memiliki kompetensi sosial yang tinggi, dari jumlah ini terdapat 39 siswa yang kepercayaan dirinya tinggi, dan 17 siswa yang memiliki kepercayaan diri rendah. Kemudian dari 47 orang yang memiliki kompetensi sosial yang rendah, dari jumlah ini terdapat 17 siswa yang kepercayaan dirinya tinggi, dan 30 siswa yang memiliki kepercayaan diri rendah.

\section{Korelasi Kompetensi Sosial dan Kepercayaan Diri}

Untuk mengkorelasikan kedua hubungan variabel tersebut apakah ada atau tidak, maka dilakukan pengujian data secara statistik dengan uji korelasional rank spearman. Bahwa dijelaskan pada uji hipotesis statistik sebelumnya yang diajukan oleh peneliti adalah sebagai berikut:

1. $\mathrm{H}_{0}: \mathrm{r}_{\mathrm{s}}=0$ Tidak terdapat hubungan antara kompetensi sosial dan kepercayaan diri pada siswa kelas $\mathrm{X}$ Madarasah Aliyah Negeri 2 Kota Bandung.

2. $\mathrm{H}_{1}: \mathrm{r}_{\mathrm{s}} \neq 0$ Terdapat hubungan antara kompetensi sosial dan kepercayaan diri pada siswa kelas X Madarasah Aliyah Negeri 2 Kota Bandung.

Berdasarkan hasil analisis statistik, diperoleh significancy-level dari pengujian yang berharga 0,000 lebih kecil dari $\alpha=$ 0,05 maka $\mathrm{H}_{0}$ ditolak dan $\mathrm{H}_{1}$ diterima dapat disimpulkan bahwa terdapat hubungan antara kompetensi sosial dan kepercayaan diri pada siswa kelas X Madrasah Aliyah Negeri 2 Kota Bandung. Yaitu dengan hasil korelasi 0,565 yang menurut kriteria Guillford (dalam Sugiyono, 2003) termasuk kategori sedang. Sedangkan koefisien determinasi diperoleh 0,32 yang menunjukkan bahwa 32 persen pada siswa yang memengaruhi variabel pertama disebabkan oleh variabel kedua dan 68 persen sisanya oleh faktor lain. 


\section{PEMBAHASAN}

Berdasarkan hasil penelitian yang diperoleh didapatkan gambaran bahwa tinggi rendahnya hubungan antara kompetensi sosial dan kepercayaan diri pada siswa kelas X Madrasah Aliyah Negeri 2 Kota Bandung memiliki jumlah yang sama. Siswa yang memiliki kompetensi sosial tinggi dan kepercayaan diri tinggi sebanyak 56 siswa atau setara dengan 54,37 persen, dan siswa yang memiliki kompetensi sosial rendah dan kepercayaan diri rendah jumlahnya 47 siswa atau setara dengan 45,63 persen. Hal ini menunjukkan bahwa siswa yang mempunyai kompetensi sosial yang tinggi juga mempunyai kepercayaan diri yang tinggi pula. Terlihat dari beberapa siswa yang aktif dan dapat memelihara hubungan dengan orang lain maka kepercayaan dirinya pun akan muncul. Sedangkan ada sebagian siswa juga yang mempunyai kompetensi sosial yang rendah maka kepercayaan dirinya pun rendah. Dalam hal ini dikarenakan siswa tidak tertarik dengan aktivitas teman-teman sebaya juga kurangnya rasa pertemanan maupun penolakan terhadap beberapa kelompok.

Berdasarkan hasil perhitungan yang terdapat pada tabel 4.5 dapat diketahui bahwa dari 103 siswa kelas X Madrasah Aliyah Negeri 2 Kota Bandung, terdapat 56 siswa yang memiliki kompetensi sosial yang tinggi. Dari jumlah ini 56 siswa tersebut terdapat 39 siswa yang kepercayaan dirinya tinggi, dan 17 siswa yang memiliki kepercayaan diri rendah. Kemudian dari 47 siswa yang memiliki kompetensi sosial yang rendah, dari jumlah ini terdapat 17 siswa yang kepercayaan dirinya tinggi, dan 30 orang yang memiliki kepercayaan diri rendah. Jadi dapat disimpulkan bahwa terdapat hubungan antara kompetensi sosial dan kepercayaan diri pada siswa kelas X Madrasah Aliyah Negeri 2 Kota Bandung.

Kesimpulan di atas juga didukung berdasarkan hasil uji statistik yang telah dilakukan, seperti yang ada dalam tabel 4.5 diketahui bahwa $\mathrm{H}_{0}$ ditolak dan $\mathrm{H}_{1}$ diterima. Hal ini menunjukkan bahwa terdapat hubungan yang signifikan antara kompetensi sosial dengan kepercayaan diri pada siswa kelas $\mathrm{X}$ Madrasah Aliyah Negeri 2 Kota Bandung. Artinya apabila kompetensi sosial tinggi, maka tingkat kepercayaan dirinya pun akan tinggi pula, sebaliknya jika kompetensi sosial yang rendah maka tingkat kepercayaan dirinya pun akan rendah.

Hal ini sesuai dengan pendapat Tentrawanti (1989), mengemukakan bahwa seseorang yang mempunyai kompetensi sosial adalah orang-orang yang mampu menarik dan mempertahankan dukungan sosial dengan memiliki ciri-ciri salah satunya adalah kepercayaan diri. Kemudian menurut Waters \& Sroufe (1983), dijelaskan bahwa kemampuan kompetensi sosial jika digunakan di lingkungan oleh individu merupakan sumber untuk mencapai keberhasilan yang baik karena akibat dari hasil perkembangan. Perkembangan kompetensi sosial memberikan beberapa hal yang dimunculkan dari isu perkembangan salah satunya adalah munculnya kepercayaan diri pada masa remaja.

Hal ini dikarenakan kompetensi sosial adalah suatu hal yang sangat penting bagi siswa dalam kehidupannya di madrasah. Beberapa siswa akan melakukan hubungan relasi sosial, agar memiliki kepercayaan diri. Siswa lebih nyaman bergaul dengan teman-teman sebayanya di madrasah. Jika teman-temanya sedang berkumpul atau sedang berdiskusi terkadang siswa ingin ikut bergabung. Siswa yang kurang percaya diri akan sulit untuk mengawali hubungan relasinya dengan teman-teman sebayanya. Adapun untuk siswa yang memiliki percaya diri tinggi maka akan mudah untuk bergaul dan berkontribusi positif dengan lingkungan sekitarnya.

Menurut Rubin \& Krasnor (1992), Kompetensi sosial adalah kemampuan individu untuk mencapai tujuan personal 
dalam interaksi sosial dengan tetap memelihara hubungan yang positif dengan orang lain setiap waktu dalam berbagai situasi.

Hal ini sesuai dengan apa yang terjadi pada siswa kelas X di Madrasah Aliyah Negeri 2 Kota Bandung. Siswa melakukan kompetensi sosial karena mereka ingin berperan aktif dan dapat menyelesaikan masalah sosial secara bersama-sama, mereka juga tidak ingin dijauhi oleh teman-teman sebayanya. Dengan melakukan kompetensi sosial oleh siswa di madrasah, maka mereka akan melakukan hal-hal yang menyangkut atau yang berhubungan dengan sosial seperti mengikuti ekstrakulikuler ataupun ikut bergabung dengan suatu kelompok diskusi.

Orang yang memiliki kompetensi sosial tinggi akan memiliki kepercayaan diri yang tinggi pula. Sedangkan orang yang memiliki kompetensi sosial yang rendah maka akan memiliki kepercayaan diri yang rendah pula. Kurangnya rasa percaya diri akan menyebabkan munculnya rasa malu, takut, dan juga akan menghambat potensi dari dalam dirinya sehingga pesimis dalam menghadapi tantangan. Oleh karena itu rasa percaya diri itu penting untuk modal menuju kesuksesan seseorang dalam menghadapi berbagai tantangan

\section{SIMPULAN}

Berdasarkan hasil penelitian dan pembahasan pada bab sebelumnya, dapat diperoleh simpulan sebagai berikut:

1. Terdapat hubungan yang signifikan antara kompetensi sosial dan kepercayaan diri pada siswa kelas $\mathrm{X}$ Madrasah Aliyah Negeri 2 Kota Bandung. Artinya apabila kompetensi sosial tinggi, maka tingkat kepercayaan dirinya pun akan tinggi pula, sebaliknya jika kompetensi sosial yang rendah maka tingkat kepercayaan dirinya pun akan rendah.

2. Tingkat kompetensi sosial tinggi dan kepercayaan diri tinggi sebanyak 56 siswa atau setara dengan 54,37 persen, dan siswa yang memiliki kompetensi sosial rendah dan kepercayaan diri rendah jumlahnya 47 siswa atau setara dengan 45,63 persen dari keseluruhan siswa.

\section{SARAN}

Berdasarkan hasil penelitian dan pembahasan yang telah dilakukan, peneliti mengajukan beberapa saran agar dapat diajukan bahan pertimbangan bagi pihak-pihak yang terkait yakni sebagai berikut:

1. Saran untuk Madrasah

Berdasarkan hasil penelitian ini, maka alangkah baiknya jika guru-guru mewajibkan siswa untuk mengikuti ekstrakulikuler sehingga bisa menumbuhkan rasa untuk menjalin relasi secara positif dan juga bisa semakin terampil dalam menjalin hubungan sosialnya.

2. Saran untuk Guru-guru

Tetap memberikan konseling oleh guru BP untuk membantu siswa dalam menggunakan dan mengembangkan bakat-bakat yang dimiliki serta mengadakan hal-hal yang berkaitan dengan masalah sosial dan kepercayaan diri anak agar lebih meningkat lagi.

3. Saran untuk Siswa

Siswa dapat mengembangkan potensi dalam dirinya. Sehingga mampu melakukan dengan maksimal sesuai dengan tujuan yang ingin dicapai. Melatih diri untuk dapat berbicara di depan kelas dan menjalin hubungan positif dengan orang lain.

4. Saran untuk Peneliti Selanjutnya

Peneliti banyak menyadari bahwa dalam penelitian ini banyak sekali kekurangannya baik dari teori yang digunakan maupun instrumen pengambilan data yang kurang optimal. Jika ada peneliti lain yang ingin meneliti dengan variabel yang sama dengan penelitian ini, diharapkan dapat lebih baik dan menyempurnakan 
penelitian ini dengan cara menambahkan referensi teori yang lebih banyak dan lebih up to date, menyusun instrumen pengambilan data secara terperinci dan lebih mendalam. Dengan demikian hasil penelitian akan lebih optimal.

\section{DAFTAR PUSTAKA}

Acocella \& Calhoun. 1995. Psikologi Tentang Penyesuaian Dan Hubungan

Kemanusiaan. Terjemah oleh Satmoko, Semarang : Ikip Semarang.

Agustina, Ira. 2011. Hubungan Resiliensi dengan Kompetensi Sosial pada Mahasiswa Psikologi UIN Sunan Gunung Djati Bandung yang Berasal dari Keluarga Bercerai. Skripsi. Jurusan Psikologi Fakultas Psikologi UIN Sunan Gunung Djati Bandung.

Ahmadi, Abu, Dr. H. 1991. Psikologi Perkembangan. Jakarta: PT. Rineke Cipta

Ali \& Asrori. 2004. psikologi remaja. Jakarta: Bumi Aksara.

Al-Uqshari, Yusuf. 2005. Percaya Diri Pasti. Jakarta: Gema Insani Press. Diunduh tanggal 12 Mei 2013 darihttp://books.google.co.id/books?i $\mathrm{d}=$ Zpm8Y3iDZiYC\&printsec $=$ frontc ove

$\& d q=$ percaya + diri $\& h l=i d \& s a=X \&$ ei $=$ sZmOUdKINYnrAeCh4GABg\&ve $\mathrm{d}=0$ CC0Q6AewAA.

Alwisol. 2004. Psikologi Kepribadian. Malang: Universitas Muhamadiyah Malang.

Angelis, De Barbara. 1997. Confidence: Percaya Diri Sukses dan Kemandirian. Jakarta: PT. Gramedia Pustaka Utama.

Arikunto, Suharsimi. 2002. Prosedur Penelitian. Jakarta: PT. Rineka Cipta.

2010. Prosedur

Penelitian. Jakarta: PT. Rineka Cipta.

Astriani. Lina. 2010. Pengaruh Kepercayaan Diri terhadap Peak
Perfomance Atlet Bola Basket Sekolah Menengah Atas (SMA) Negeri di Kota Malang. Fakultas Psikologi UIN Maulana Malik Ibrahim Malang. Skripsi. Diunduh tanggal 10 Desember 2012 dari http://lib.uinmalang.ac.id/thesis/fullchapter/0441 0066-lina-astriani.ps.

Azwar, Saifuddin. 1999. Reliabilitas dan Validitas. Yogyakarta: Pustaka Pelajar.

$\begin{array}{ll} & \text { 2004. Reliabilitas dan } \\ \text { Validitas. } & \text { Yogyakarta: Pustaka }\end{array}$ Pelajar. 2009. Penyusunan Skala Psikologi. Yogyakarta: Pustaka Pelajar.

Creswell, John W. 2010. Research Design Pendekatan kualitatif, Kuantitatif dan Mixed. Yogyakarta: Pustaka Pelajar.

Darajat, Zakiah. 1990. Kesehatan Mental. Jakarta: Gunung Agung.

Denham, S., A.,\& Queenan, P., 2003. Preschool Emotional Competence: Pathway To Social Competence. Journal Of Child Development. Vol. 74, No 1, 238-256.

Denny, Richard. 2007. Motivate to win Edisi III-Cara Memotivasi Diri Sendiri dan Orang lain. Jakarta: PT Gramedia Pustaka Utama. Diunduh tanggal 12 Mei 2013 dari http://books.google.co.id/books?id= YKG9BTOV2n0C\&pg=PA43\&dq=p eraya+diri\&hl=id\&sa=X\&ei=sZmO UdKINYnrAeCh4GABg\&ved=0CE8 Q6AEwBw

Friedenberg, Lisa. 1995. Psychological Testing, Design, Analysis and Use. Allyn and Bacon.

Gunarsa. 1990. Psikologi Remaja. Jakarta; PT BPK Gunung Mulia.

Guildford, J.P. and Benjamin Fruchter. Fundamental Statistics in Psychology and Education. New York: McGraw-Hill, 1973. 
Hakim, Thursan. 2002. Mengatasi Rasa Tidak Percaya Diri. Jakarta: Puspa Swara.

Hurlock, EB. 1999. Psikologi Perkembangan, Suatu Pendekatan Sepanjang

Rentang Kehidupan. Edisi kelima. Jakarta: Penerbit Erlangga.

Hurlock, EB. 1980. Psikologi Perkembangan. Edisi kelima. Jakarta: Penerbit Erlangga.

Katz, Samantha. 2004. Social and Personality Development.

Powerpoint. Diunduh tanggal 10 Desember 2012.

Krasnor, $\mathrm{R}$ et al. 1996. International Journal of Behavior Development. American Psychological Association.

Latifah, L., 2000. Kompetensi Sosial, Status Sosial, dan Viktimisasi Disekolah Dasar. Skripsi (Tidak Diterbitkan), Yogyakarta: Fakultas Psikologi Universitas Gajah Mada.

Lauter, P. 2002. Tes Kepribadian. Jakarta: Gaya Media Pratama.

Lindenfield, Gael. 1997. Mendidik Anak agar Percaya Diri (alih bahasa: Ediati Kamil). Jakarta: Arcan.

Lindenfield, Gael. 1994. Confident Children. Glasgow. Harper Collins Publisher.

L'abate, L. 1990. Building Family Competence Primary and Secondary Prevention Strategies. London: Sage Publication.

Papalia, Olds. Feldman. 2002. Human Development - Perkembangan Manusia

edisi 10. Kota Jakarta: Penerbit Salemba Humanika.

Rifki, Mustofa. 2008. Pengaruh Rasa Percaya Diri terhadap Prestasi

Belajar Siswa di SMA Islam Al-Maarif Singosari Malang. Jurusan Pendidikan Ilmu Pengetahuan Sosial Fakultas Tarbiyah UIN Malang. Skripsi. Diunduh tanggal 10 Desember 2012 dari http://lib.uin- malang.ac.id/thesis/fullchapter/0316 0015-mustofa-rifki.ps.

Rohman, Ujang \& Yuliana, Neneng. 2010. Hubungan Konsep Diri dengan

Kompetensi Sosial pada Siswa Kelas VIII MTS Ad-Dawa Bekasi Tahun Pelajaran 2006-2007. Fakultas Psikologi UIN. Psympathic, Jurnal Ilmiah Psikologi. No1:45-58 Vol.III tahun 2010.

Rubin, K.H., \& Rose-Krasnor, L. (1992). Interpersonal problem solving and social competence in children. In V.B. Van Hasselt \& M. Hersen (Eds.). Handbook of Social Development : A Lifespan Perspective (pp. 283323). New York: Plenum Press.

Santrock, John W. 2002. Life Span Development-Perkembangan Masa Hidup

edisi kelima jilid 2. Kota Jakarta: Penerbit Erlangga.

Santrock, John W. 2003. Adolescence perkembangan remaja edisi 6. Jakarta:

Erlangga.

Siegel, Sydney. 1992. Statistik Nonparametrik Untuk Ilmu-Ilmu Sosial. Jakarta: PT Gramedia Pustaka Utama.

Sudianto, Asep. 2007. Hubungan Antara Kompentensi Sosial Dengan Prestasi Akademik Pada Mahasiswa Fakultas Psikologi Uin Malang. Skripsi. Fakultas Psikologi UIN Malang. Diunduh tanggal 14 Mei 2013-05-17 dari http://lib.uinmalang.ac.id/thesis/fullchapter/0341 0075-asep-sudianto.ps

Sudjana. 1992. Metode Statistika. Bandung: Penerbit Tarsito. 2005. Metode Statistika. Bandung: Penerbit Tarsito.

Sugiyono. 2003. Metode Penelitian Pendidikan Pendekatan Kuantitatif,Kualitatif,

dan $\quad R \& D$. Bandung:Alfabeta. 